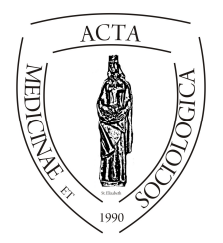

Acta Medicinae et

doi:

\title{
Egészséges táplálkozással kapcsolatos szokások egyetemi hallgatók körében
}

\author{
Koroknay Zsuzsa ${ }^{1}$, Pfau Christa ${ }^{2}$ \\ ${ }^{1}$ PhD hallgató, Debreceni Egyetem, Gazdaságtudományi Kar, Sportgazdasági és -menedzsment Intézet \\ ${ }^{2}$ Egyetemi adjunktus, Debreceni Egyetem, Gazdaságtudományi Kar, Sportgazdasági és -menedzsment \\ Intézet
}

\section{INFO}

\section{Koroknay Zsuzsa}

koroknay.zsu-

zsa@econ.unideb.hu

\section{Keywords:}

fruit and vegetable consumption, fluid intake, university students

\section{ABSTRACT}

\section{Kulcsszavak:}

Gyümölcs és zöldségfogyasztás, folyadékbevitel, egyetemi hallgatók

\begin{abstract}
The leisure time and the number of healthy lifestyle people are increasing at same time, what creating several health trends. These health trends affect two basic elements of a healthy lifestyle, physical activity and healthy diet. In this research, we examined the healthy diet, including two segments; vegetable and fruit consumption and fluid intake. The test sample was made by the students of the University of Debrecen. As a research method, we also performed primary and secondary research. In the case of secondary research, we also reviewed the international and national literatures, and compared the American and European healthy diet recommendations. In the case of primary research, we did a survey, during which we measured the healthy eating habits of the students. Our research shows that only $11,3 \%$ of the surveyed students consume vegetables and fruits what complies with the daily recommendations. However, in the case of fluid consumption, we got better result. The $65 \%$ of the respondents consume the appropriate amount of fluids.
\end{abstract}

Absztrakt: A szabadidő növekedésével párhuzamosan nött az emberek egészséges életmódra való törekvésével, mely különböző egészségtrendeket hozott létre. Ezen egészségtrendek az egészséges életmód két alapvető elemét érintik, a fizikai aktivitást és egészséges táplálkozást. Jelen tanulmányban a két elem közül az egészséges táplálkozást vizsgáltuk meg, annak is két szegmensét; a zöldség- és gyümölcsfogyasztást, valamint a folyadékbevitelt. A vizsgálati mintát a Debreceni Egyetem hallgatósága adta. Kutatási módszerként primer és szekunder vizsgálatot is végrehajtottunk. Szekunder kutatás esetében a nemzetközi és hazai irodalmat tekintettük át, valamint az amerikai és európai ajánlásokat hasonlítottuk össze. Primer kutatás esetében kérdőíves megkérdezés történt, mely 
során a hallgatók egészséges táplálkozási szokásait mértük fel. Kutatásunk során megállapításra került, hogy a felmért hallgatók mindössze 11,3\%-a fogyaszt napi rendszerességgel az ajánlásoknak megfelelö zöldséget és gyümölcsöt. A folyadékfogyasztás esetében azonban kedvezőbb eredményt kaptunk. A megkérdezettek 65\%-a fogyaszt legalább az ajánlásoknak megfelelö mennyiségü folyadékot.

„A publikáció elkészítését az EFOP-3.6.1-16-2016-00022 számú, Debrecen Venture Catapult Program címü projekt támogatta. A projekt az Európai Unió támogatásával, az Európai Szociális Alap társfinanszírozásával valósult meg."

\section{Bevezető}

Napjainkban egyre nagyobb szerepet kap az egészség, az egészséges életmód. Az egészséggel foglalkozó kutatások igen összetettek, hiszen számos oldalról megközelíthető és sok vizsgálandó eleme van. Jelen vizsgálatban az egészséges életmód egy elemét vizsgáltuk meg, a táplálkozást. Az egészséges életmódra vonatkozóan egyre több tanulmány jelenik meg nemcsak a felnőtt lakosságra, hanem fiatal felnőttekre, egyetemistákra vonatkozóan is. Kutatásunkkal ezen palettát kívánjuk kibővíteni, hiszen vizsgálatunk során a Debreceni Egyetem hallgatói körében mértük fel az egészséges táplálkozás két komponensét, a zöldség- és gyümölcsfogyasztást, valamint a folyadékbevitelt.

\section{Egészséges táplálkozás}

A kiegyensúlyozott táplálkozás fontos összetevője a rendszeres zöldség- és gyümölcsfogyasztás. A zöldségek és gyümölcsök $75-95 \%$ víz, ám jelentőségük abban rejlik, hogy megfelelő forrást biztosítanak az élelmi rost szükséglet fedezéséhez és vitaminpótlásban és ásványi anyag egyensúly fenntartásában is nélkülözhetetlenek (Mednyánszky, 2002). Mindemellett olyan növényi szterolokat, flavonoidokat és más antioxidánsokat tartalmaznak, amely esszenciális tápanyagokat a zöldség és gyümölcsfogyasztás megfelelő bevitele képes biztosítani a szervezet számára (WHO, 2019).

Számos kutatás foglalkozik az egészséges táplálkozás okozta pozitív hatásokkal, amelyek alátámasztották, hogy a megfelelő táplálkozás hozzájárul az egészség megőrzéséhez és a jó közérzet kialakulásában is szerepet vállal (Niva, 2007). Mindezek ellenére az egészségfelmérések eredményei azt mutatják, hogy az egészséget veszélyeztető kockázati tényezők közül a viselkedés okozta kockázatok, azon belül is a táplálkozási kockázati tényezők a leggyakoribbak. Ilyen például a túlsúly, elhízás, magas koleszterin-, vércukorszint vagy vérnyomás, túlzott só fogyasztás (Vitrai, Bakacs és Varsányi, 2017). A zöldség- és gyümölcsfogyasztásnak fontos szerepe lehet olyan betegségek kialakulásának megelőzésében, mint például a nem fertőző betegségek 
(NDCs), kardiovaszkuláris betegségek, az agyvérzés vagy bizonyos ráktípusok esetében, például gyomor- és vastagbél rák (Pfau, Müller és munkatársai, 2018, WHO, 2019). Becslések szerint világszerte 3,9 millió haláleset következett be a nem megfelelő gyümölcs- és zöldségfogyasztás végett 2017-ben (WHO, 2019).

Az Elef által készített 2014-es felmérése arról számol be, hogy Magyarország az EU 28 tagállamából a 12. helyen áll a napi szintü zöldség- és gyümölcsfogyasztásban. Ha a táplálkozási ajánlásoknak megfelelő napi öt vagy több adag gyümölcs fogyasztását figyeljük, akkor a rangsorban hátrébb kerülünk, ugyanis ebben az esetben az EUátlag (14\%) alatt, 10\%-kal teljesítünk (Elef 2014, 2018).

Az egészséges táplálkozást azonban számos tényező is befolyásolhatja. A négy fó szint - az egyéni (intraperszonális), szociális környezet (interperszonális), fizikai környezet (közösségi környezet), makro környezet - mellett fontos figyelembe venni az egyetemi jellemzőket. Ilyen jellemző a rezidencia, hallgatói közösség, vizsgák, egyetemi életmód többek között (Deliens, Clarys és munkatársai, 2014). Jelen kutatásom során ezeket a befolyásoló tényezőket nem vettem figyelembe, azonban szándékomban áll egy későbbi kutatásban előtérbe helyezni.

\section{Zöldség- és gyümölcsfogyasztási ajánlások}

De hogy pontosan mennyi is az ajánlott napi fogyasztási mennyiség? A legfrissebb amerikai étkezési útmutató (Dietry Guidelines, 2015) tartalmazza az amerikaiak napi ajánlásait. Meghatároztak egy egészséges étkezési mintát, mely utasításokat tartalmaz azzal kapcsolatban, hogy milyen mennyiségben szükséges zöldséget, gyümölcsöt, fehérjét, tejterméket, gabonaféléket és olajokat fogyasztani; valamint limitet határoz meg telített- és transzzsírsavakra, só- és cukorbevitelre. A Guidelines (2015) tartalmaz egy úgynevezett amerikai egészséges étkezési mintát (Healthy U.S.-Style Eating Pattern), melyben leírásra kerül egy általános, 2000 kilokalóriás összeállítás étkezési csoportok szerint. Az ajánlás mértékegysége a „cup”, ami hazánkban is egyre inkább elterjedt és 1 cup, azaz 1 csésze mennyiség körülbelül 240 grammnak felel meg. Az ajánlás alapján elmondható, hogy gyümölcsből napi 2 cup mennyiség ajánlott, míg zöldségből 2,5 cup, ám ebben a kategóriában további részkategóriák kerültek kialakításra. Ezen részkategóriák a következők: Sötétzöld (Dark Green), melyből 1,5 cup/hét az ajánlás, míg a piros és narancssárga (Red \& Orange) kategóriába tartozó zöldségekből 5,5 cup/hét. A hüvelyesekből (Legumes) hetente 1,5 cup, a keményítöt tartalmazó zöldségekböl (Starchy) heti 5 cup, míg egyéb zöldségekből (Other) 4 cup/hét az ajánlott fogyasztási mennyiség. A sötétzöld kategóriába tartozik például a brokkoli, spenót, bok choy, zöld füszernövények, kelkáposzta. A piros és narancssárga kategóriába a paradicsom, sárgarépa, paradicsomlé, édes burgonya, piros paprika, sütőtök; hüvelyesek kategóriába a bab, lencse, csicseriborsó; keményítőt tartalmazó zöldségek közé tartozik a krumpli, kukorica, manióka, zöldborsó; végezetül pedig az egyéb kategóriába tartoznak többek között az uborka, jégsaláta, hagyma, zöldbab, karfiol, padlizsán, avokádó, gomba, cukkini, spárga (Dietary Guidelines, 2015). 
Természetesen minden embernek más a napi energiaszükséglete, amelyet a kor, nem és edzettségi állapot is befolyásol. Ebből adódóan az ajánlás végén látható egy kilokalória táblázat, mely az előbbiekben említett befolyásoló tényezőket szem előtt tartva meghatározza, hogy nemre, korra és fizikai aktivitásra vonatkozóan mekkora napi energiabevitel szükséges. Így mindenki meg tudja határozni magának, hogy mekkora napi energiaszükséglete van. Mivel vannak ismétlődő értékek, így ezekre vonatkozóan is készítettek ajánlásokat. Egy kibővített táblázat került kialakításra, mely 12 kilokalória szint napi ajánlásait mutatja be, melyek közül 6 szint bemutatásra kerül jelen tanulmányban is (1. táblázat) (Dietary Guidelines, 2015).

\begin{tabular}{|c|c|c|c|c|c|c|}
\hline \multirow{2}{*}{ Ételcsoportok } & \multicolumn{6}{|c|}{ Kilokalória szintek } \\
\hline & 1000 & 1400 & 1800 & 2200 & 2600 & 3000 \\
\hline Zöldség (cup/nap) & 1 & $1 \frac{1 / 2}{2}$ & $2 \frac{1}{2}$ & 3 & $3 \frac{1}{2}$ & 4 \\
\hline Sötétzöld zöldségek (cup/hét) & $1 / 2$ & 1 & $1 \frac{1}{2}$ & 2 & $2 \frac{1}{2}$ & $21 / 2$ \\
\hline $\begin{array}{l}\text { Piros és narancssárga zöldségek } \\
\text { (cup/hét) }\end{array}$ & $21 / 2$ & 3 & $51 / 2$ & 6 & 7 & $71 / 2$ \\
\hline Hüvelyesek (cup/hét) & $1 / 2$ & $1 / 2$ & $1 \frac{1}{2}$ & 2 & $2 \frac{1}{2}$ & 3 \\
\hline $\begin{array}{l}\text { Keményítőt tartalmazó zöldségek } \\
\text { (cup/hét) }\end{array}$ & 2 & $31 / 2$ & 5 & 6 & 7 & 8 \\
\hline Egyéb (cup/hét) & $11 / 2$ & $2 \frac{1}{2}$ & 4 & 5 & $5 \frac{1}{2}$ & 7 \\
\hline Gyümölcs (cup/nap) & 1 & $1 \frac{1}{2}$ & $1 \frac{1 / 2}{2}$ & 2 & 2 & $21 / 2$ \\
\hline
\end{tabular}

Forrás: Saját szerkesztés Dietary Guidelines (2015) alapján, 2019

1. táblázat: Amerikai étkezési minta zöldség- és gyümölcsfogyasztás esetén kalóriaszint bontásban

A WHO (2018a) egészséges diéta kiadványában ajánlásokat fogalmazott meg, amelyek Európában elfogadottak. Az írás olyan megállapítást is tartalmaz, mely szerint az emberek több energiát, zsírt, szabad cukrot és sót / nátriumot fogyasztanak, és sokan nem fogyasztanak elég gyümölcsöt, zöldséget és egyéb élelmi rostot, például teljes kiőrlésü gabonát. Ezen ajánlás is hasonlóan vélekedik az amerikaihoz, mely szerint a diverzifikált, kiegyensúlyozott és egészséges táplálkozás pontos összetétele az egyéni jellemzőktől is függ (pl. kor, nem, életmód és fizikai aktivitás mértéke), valamint a kulturális környezet, a helyben elérhető élelmiszerek és az étrendszokások is befolyásolják az emberek étkezését. Az egészséges táplálkozás alapelvei azonban ugyanazok maradnak (WHO, 2018a). Az egészséges táplálkozás alkotóelemei a gyümölcsök, zöldségek, hüvelyesek, diófélék és teljes kiőrlésű gabonafélék. A zöldség- és gyümölcsfogyasztásra vonatkozóan az ajánlás 400 grammot vagy öt adagot ír elö, mely nem tartalmazza a gumós zöldségeket (krumpli, édesburgonya, manióka stb.). Az ajánlás szerint a gyümölcs és zöldségfogyasztás javítható, ha étkezésünk mindig tartalmaz valamilyen zöldséget vagy gyümölcsöt. Ezeket fogyaszthatjuk snackként, valamint változatosan és szezonális termékeket is érdemes étkezési rutinunkba beiktatni (WHO, 2018a).

A két ajánlás összevetése alapján elmondható, hogy a zöldség- és gyümölcsfogyasztás ajánlott napi bevitele legalább 400 gramm vagy 5 darab zöldség és/vagy gyümölcs. 


\section{Folyadékbevitel ajánlás}

A folyadékfogyasztás az egészséges táplálkozás másik fő komponense. Gandy (2015) írásában az EFSA (Európai Élelmiszerbiztonsági Hatóság) és az IOM (Amerikai Orvostudományi Intézet) által közreadott folyadékszükségleti ajánlásokat mutatja be. Nemre és korra vonatkozó speciális ajánlást tettek, melyet teljes vízfelvételre és folyadékbevitelre bontanak. A két érték közötti különbséget a táplálékból származó vízmennyiség adja. A tanulmány szempontjából releváns részt a 2 . táblázat mutatja be.

\begin{tabular}{|l|c|c|c|c|}
\hline \multirow{2}{*}{ Nem } & \multicolumn{4}{|c|}{ Megfelelő mennyiség (1/nap) } \\
\cline { 2 - 5 } & \multicolumn{2}{|c|}{ EFSA } & \multicolumn{2}{c|}{ IOM } \\
\cline { 2 - 5 } & Teljes vízfelvétel & Folyadékbevitel & Teljes vízfelvétel & Folyadékbevitel \\
\hline Férfi & 2,50 & 2,00 & 3,30 & 2,60 \\
\hline Nő & 2,00 & 1,60 & 2,30 & 1,80 \\
\hline
\end{tabular}

Forrás: Saját szerkesztés Gandy (2015) alapján, 2019

2. táblázat: Ajánlott vízfelvétel

A két ajánlás között a férfiak esetében a teljes vízfelvételkor 0,8 liter, míg a folyadékbevitelkor 0,6 liter különbség látható. A nők vízfelvétele esetében 0,3 liter, míg folyadékbevitel során 0,2 liter különbség van. Az ajánlások közötti különbséget a meghatározás módszere adhatja. Az IOM a napi ajánlást a nemzeti mérések során tapasztalt számadatok mediánjai alapján határozta meg, míg az EFSA tudományos módszerek alapján állapította meg a napi ajánlott folyadékszükségletet.

Egy másik, szintén részletes folyadékszükségleti ajánlás található Jéquier és Constant (2010) müvében, melyet a 3. táblázat mutat be. Ez az ajánlás szintén nem és kor szerinti bontásban mutatja be a fogyasztani szükséges napi mennyiséget. Ám ebben az esetben a gyümölcsből származó ajánlott folyadékmennyiség is feltüntetésre került. A felnőtt férfiak esetében az átlagos napi folyadékbevitel mennyisége 2,5 liter, míg a nők esetében 2 liter.

\begin{tabular}{|c|c|c|c|c|c|c|}
\hline \multirow{2}{*}{$\begin{array}{c}\text { Életsza- } \\
\text { kasz }\end{array}$} & \multicolumn{3}{|c|}{$\begin{array}{c}\text { Ajánlott folyadékfogyasztás férfiak- } \\
\text { nál (ml/nap) }\end{array}$} & \multicolumn{3}{|c|}{$\begin{array}{c}\text { Ajánlott folyadékfogyasztás nőknél } \\
\text { (ml/nap) }\end{array}$} \\
\cline { 2 - 7 } & Italból & $\begin{array}{c}\text { Gyümölcs- } \\
\text { böl }\end{array}$ & $\begin{array}{c}\text { Összes folya- } \\
\text { dék }\end{array}$ & $\begin{array}{c}\text { Ital- } \\
\text { ból }\end{array}$ & $\begin{array}{c}\text { Gyümölcs- } \\
\text { böl }\end{array}$ & $\begin{array}{c}\text { Összes fo- } \\
\text { lyadék }\end{array}$ \\
\hline 2-3 éves & 910 & 390 & 1300 & 910 & 390 & 1300 \\
\hline $4-8$ éves & 1120 & 480 & 1600 & 1120 & 480 & 1600 \\
\hline 9-13 éves & 1470 & 630 & 2100 & 1330 & 570 & 1900 \\
\hline $\begin{array}{c}14 \text { évnél } \\
\text { több }\end{array}$ & 1750 & 750 & 2500 & 1400 & 600 & 2000 \\
\hline
\end{tabular}

Forrás: Saját szerkesztés Jéquier - Constant (2010) alapján, 2019

3. táblázat: Napi ajánlott folyadékbevitel 
Ezen ajánlások alapján megfigyelhető, hogy az amerikai és európai ajánlás eltér. Ám összességében elmondható, hogy a felnőtt lakosok számára az ajánlott folyadékmenynyiség a legalább 2 liter.

\section{Anyag és módszer}

Kutatásunk során primer és szekunder vizsgálatot is végrehajtottunk. Szekunder kutatás esetében a nemzetközi és hazai irodalmat tekintettük át, illetve az amerikai és európai ajánlásokat hasonlítottuk össze. Primer kutatás esetében kérdöíves megkérdezés történt, mely során a hallgatók egészséges táplálkozási szokásait mértük fel.

A kérdőíves megkérdezés papír alapon történt, hiszen ennek a módszernek az alkalmazásával olyan hallgatók is bekerültek a vizsgálati mintába, akik nem végeznek sem szabadidős-, sem versenysport tevékenységet. A megkérdezés során kapott adatokat közvetlenül az IBM SPSS Statistics 22 programban rögzítettük úgy, hogy minden kérdés válaszát kódoltuk, annak érdekében, hogy egyszerübbé tegyük a későbbi statisztikai vizsgálatok elvégzését. Jelen tanulmányban a kiszámított alapstatisztikai mutatók és kereszttáblás vizsgálatok értékelését mutatjuk be.

A vizsgálati mintába 266 fö került be, melynek $45 \%$-a nő, 55\%-a férfi. A felmért hallgatók település hely szerinti megoszlásáról elmondható, hogy 82,2\% megyei jogú városban vagy városban van az állandó lakhelye, míg 17,8\%-uk község, falu vagy tanya településtípusból származik. A válaszadók a Debreceni Egyetem 10 karát képviselik. Legnagyobb arányban a Gazdaságtudományi Kar hallgatói (70,7\%), míg a legkisebb arányban az Állam- és Jogtudományi Kar hallgatója $(0,4 \%)$. Évfolyamok tekintetében a legnagyobb százalékban az első éves hallgatók (alap-, mester és osztatlan képzésben résztvevők összesen) vettek részt a kutatásban $(39,6 \%)$, míg volt egy Pszichológus szakos hallgató, aki egyedüliként hetedik évfolyamos.

Az eredmények tisztánlátása végett szükséges megemlíteni, hogy a kérdőívben nem tértünk ki a folyadék pontos meghatározására. Ezáltal a folyadékfogyasztásba a kapott eredmények esetében az üdítőitalokat is belekalkulálhatták a válaszadók. Ezek alapján a kutatásban a folyadékfogyasztási szükségletnek tesz eleget a mintában résztvevők többsége.

\section{Eredmények}

A korábbiakban írtaknak megfelelően az eredményeinket zöldség- és gyümölcsfogyasztás, valamint folyadékbevitel bontásban ismertetjük. Ezt követően a két vizsgálati területet együttesen elemezzük kereszttábla segítségével.

A megkérdezettek gyümölcsfogyasztási gyakoriságát a 4. táblázat mutatja be. A táblázatban látható százalékos értékek az adott nem összlétszámához viszonyított arányt mutatják. A táblázat értékei ideális esetben mind létszám, mind százalékos adatokban csökkenő ütemet kellene mutatnia. Ám látható, hogy az adatok a hetente 1-3 alkalommal fogyasztó gyakoriságnál csúcsosodnak ki. A százalékos értékek alapján 
elmondható, hogy a nemek között nem figyelhető meg nagyarányú különbség a gyümölcsfogyasztás gyakoriságára vonatkozóan. Összességében megállapítható, hogy a válaszadók 20,67\%-a fogyaszt napi szinten valamilyen gyümölcsöt.

\begin{tabular}{|c|c|c|c|c|c|}
\hline Nem & $\begin{array}{c}\text { Na- } \\
\text { ponta }\end{array}$ & $\begin{array}{c}\text { Hetente 4-6 alka- } \\
\text { lommal }\end{array}$ & $\begin{array}{c}\text { Hetente 1-3 alka- } \\
\text { lommal }\end{array}$ & $\begin{array}{c}\text { Ritkábban, mint } \\
\text { hetente }\end{array}$ & Soha \\
\hline Férfi (fó) & 28 & 31 & 58 & 24 & 4 \\
\hline Férfi (\%) & $19,3 \%$ & $21,4 \%$ & $40,0 \%$ & $16,6 \%$ & $2,8 \%$ \\
\hline Nö (fö) & 27 & 32 & 47 & 14 & 1 \\
\hline Nö (\%) & $22,3 \%$ & $26,4 \%$ & $38,8 \%$ & $11,6 \%$ & $0,8 \%$ \\
\hline
\end{tabular}

Forrás: Saját szerkesztés, 2019

4. táblázat: Gyümölcsfogyasztás gyakorisága nem szerinti bontásban

Az egyetemi hallgatóság válaszait a zöldségfogyasztás gyakoriságára vonatkozóan az 5. táblázat szemléleti. Az előző táblázathoz hasonlóan a százalékos értékek az adott nem összlétszámához viszonyított hányadát mutatja. A naponta zöldséget fogyasztók számában a gyümölcsfogyasztáshoz képest csökkenést láthatunk, ami kedvezőtlen. A nemek közötti százalékos arányokat összehasonlítva elmondható, hogy zöldségfogyasztás esetében sem figyelhető meg nagy százalékos eltérés. Összességében tehát a vizsgálatban résztvevők $17,3 \%$ fogyaszt napi szinten zöldséget.

\begin{tabular}{|c|c|c|c|c|c|}
\hline Nem & $\begin{array}{c}\text { Na- } \\
\text { ponta }\end{array}$ & $\begin{array}{c}\text { Hetente 4-6 alka- } \\
\text { lommal }\end{array}$ & $\begin{array}{c}\text { Hetente 1-3 alka- } \\
\text { lommal }\end{array}$ & $\begin{array}{c}\text { Ritkábban, mint } \\
\text { hetente }\end{array}$ & Soha \\
\hline Férfi (fö) & 26 & 19 & 66 & 30 & 4 \\
\hline Férfi (\%) & $17,9 \%$ & $13,1 \%$ & $45,5 \%$ & $20,7 \%$ & $2,8 \%$ \\
\hline Nö (fö) & 20 & 21 & 57 & 21 & 2 \\
\hline Nő (\%) & $16,5 \%$ & $17,4 \%$ & $47,1 \%$ & $17,4 \%$ & $1,7 \%$ \\
\hline
\end{tabular}

Forrás: Saját szerkesztés, 2019

5. táblázat: Zöldségfogyasztás gyakorisága nem szerinti bontásban

A két fogyasztás közötti hasonlóság abban rejlik, hogy mindkét esetben a legnagyobb értékek a hetente 1-3 alkalommal fogyasztási gyakoriságnál láthatóak. Tehát az ideális állapottól pontosan ugyanabba az irányba tolódnak el az értékek mindkét esetben mind a nök, mind a férfiak tekintetében. Ezen megállapításokat az 6. táblázat szemlélteti is. A legnagyobb arányban $(25,2 \%)$ azok vannak, akik mind zöldségböl, mind gyümölcsből hetente 1-3 alkalommal fogyasztanak - 67 fö. A naponta fogyasztók száma ebben a kereszttáblában pedig tovább romló eredményt mutat, hiszen mindöszsze 30 fő táplálkozik az ajánlásoknak megfelelően napi szinten zöldséget és gyümölcsöt, ami a megkérdezettek csupán 11,3\%-t teszi ki. A két változó között függőségi kapcsolat áll fenn a khi ${ }^{2}$ próba eredménye alapján. A szimmetrikus mutatók eredményei pedig erős kapcsolatot mutatnak, hiszen a Phi értéke 0,912. 


\begin{tabular}{|c|c|c|c|c|c|c|}
\hline \multirow{2}{*}{$\begin{array}{l}\text { Milyen gyakran fogyaszt } \\
\text { gyümölcsöt vagy frissen fa- } \\
\text { csart gyümölcs levét? }\end{array}$} & \multicolumn{5}{|c|}{$\begin{array}{l}\text { Milyen gyakran fogyaszt zöldséget, salátát vagy } \\
\text { frissen facsart zöldség levét? }\end{array}$} & \multirow{2}{*}{$\begin{array}{l}\text { To- } \\
\text { tal }\end{array}$} \\
\hline & $\begin{array}{l}\mathrm{Na}- \\
\text { ponta }\end{array}$ & $\begin{array}{l}\text { Hetente } 4- \\
6 \text { alkalom- } \\
\text { mal }\end{array}$ & $\begin{array}{l}\text { Hetente 1- } \\
3 \text { alkalom- } \\
\text { mal }\end{array}$ & $\begin{array}{l}\text { Ritkábban, } \\
\text { mint he- } \\
\text { tente }\end{array}$ & Soha & \\
\hline Naponta & 30 & 10 & 15 & 0 & 0 & 55 \\
\hline Hetente 4-6 alkalommal & 5 & 22 & 31 & 4 & 1 & 63 \\
\hline Hetente 1-3 alkalommal & 7 & 6 & 67 & 24 & 1 & 105 \\
\hline Ritkábban, mint hetente & 4 & 2 & 9 & 22 & 1 & 38 \\
\hline Soha & 0 & 0 & 1 & 1 & 3 & 5 \\
\hline Total & 46 & 40 & 123 & 51 & 6 & 266 \\
\hline
\end{tabular}

Forrás: Saját szerkesztés, 2019

6. táblázat: Gyümölcs- és zöldségfogyasztás gyakoriság kereszttáblás vizsgálata

Készítettünk két kereszttáblás vizsgálatot (7. táblázat, 8. táblázat), ami megmutatja, hogy az ajánlott napi mennyiség elfogyasztása megtörténik e, és hogy ez hogyan is oszlik meg a gyakorisági adatokkal összevetve. A gyümölcsfogyasztásra vonatkozó kereszttáblás (7. táblázat) vizsgálat eredményei megmutatják, hogy a válaszadók mindössze $30 \%$ fogyaszt napi szinten az ajánlásoknak megfelelő mennyiséget ( 79 fö). Mindez azonban nincs összhangban azzal, hogy a 20,67\%-kal, ami a fogyasztási gyakoriságra kérdez rá (55 fö).

\begin{tabular}{|c|c|c|c|c|c|c|}
\hline \multirow{2}{*}{$\begin{array}{c}\text { Naponta fogyaszt legalább } 5 \text { darab nyers } \\
\text { zöldséget (burgonya és zöldséglé nélkül) } \\
\text { és/vagy gyümölcsöt? (Összmennyiség } 400 \\
\text { g) }\end{array}$} & \multicolumn{5}{|c|}{$\begin{array}{l}\text { Milyen gyakran fogyaszt gyümölcsöt vagy } \\
\text { frissen facsart gyümölcs levét? }\end{array}$} & \multirow{2}{*}{$\begin{array}{l}10- \\
\text { tal }\end{array}$} \\
\hline & $\begin{array}{l}\mathrm{Na}- \\
\text { ponta }\end{array}$ & $\begin{array}{l}\text { Hetente } \\
\text { 4-6 alka- } \\
\text { lommal }\end{array}$ & $\begin{array}{l}\text { Hetente } \\
1-3 \text { alka- } \\
\text { lommal }\end{array}$ & $\begin{array}{c}\text { Ritkáb- } \\
\text { ban, mint } \\
\text { hetente }\end{array}$ & Soha & \\
\hline Igen & 34 & 20 & 20 & 5 & 0 & 79 \\
\hline $\mathrm{Nem}$ & 21 & 43 & 85 & 33 & 5 & 187 \\
\hline Total & 55 & 63 & 105 & 38 & 5 & 266 \\
\hline
\end{tabular}

Forrás: Saját szerkesztés, 2019

7. táblázat: Gyümölcsfogyasztásra vonatkozó kereszttáblás vizsgálat

Mindezek alapján elmondható, hogy a válaszadók közül 34 fő fogyaszt napi szinten megfelelő mennyiségü gyümölcsöt, ami csak 12,7\%. A kereszttáblás vizsgálat ismérvei közötti kapcsolat elemzéséhez $\mathrm{khi}^{2}$ próbát kértem, melynek eredménye alapján szignifikáns kapcsolat van a két változó között $(\mathrm{p}<0,05)$. A Phi és Cramer's V értékei pedig pontosan 0,388 , ami azt mutatja, hogy a két változó között gyenge erősségü függőségi kapcsolat áll fenn.

A zöldségfogyasztásra vonatkozó kereszttábla (8. táblázat) értéke alapján szintén látható, hogy 79 fő fogyaszt napi szinten ajánlott mennyiségü zöldséget. De ebben az esetben is az figyelhető meg, hogy a gyakorisági adatokkal nincs összhangban a vá- 
lasz, hiszen a megkérdezettek 17,3\%-a fogyaszt napi szinten zöldséget. Ezen két ismérv keresztmetszetében pedig 29 fő található, akikre igaz az az állítás, hogy napi szinten fogyasztanak megfelelő mennyiségü zöldséget, ami mindössze a vizsgálati mintában résztvevők 10,1\%-a. A kereszttábla ismérvei között függőségi kapcsolat áll fenn, hiszen a khi ${ }^{2}$ próba alapján szignifikánsak az eredmények. A kapcsolat erősségét mutató Phi és Cramer's V értéke 0,423, tehát közepesen erős függőségi kapcsolat áll fenn a két változó között.

\begin{tabular}{|c|c|c|c|c|c|c|}
\hline \multirow{2}{*}{\begin{tabular}{|c|} 
Naponta fogyaszt leg- \\
alább 5 darab nyers zöld- \\
séget (burgonya és zöld- \\
séglé nélkül) és/vagy \\
gyümölcsöt? (Összmeny- \\
nyiség $400 \mathrm{~g}$ )
\end{tabular}} & \multicolumn{5}{|c|}{$\begin{array}{l}\text { Milyen gyakran fogyaszt zöldséget, salátát vagy frissen } \\
\text { facsart zöldség levét? }\end{array}$} & \multirow{2}{*}{ Total } \\
\hline & Naponta & $\begin{array}{l}\text { Hetente 4-6 } \\
\text { alkalommal }\end{array}$ & $\begin{array}{l}\text { Hetente 1-3 } \\
\text { alkalommal }\end{array}$ & $\begin{array}{l}\text { Ritkábban, } \\
\text { mint hetente }\end{array}$ & Soha & \\
\hline Igen & 29 & 18 & 29 & 3 & 0 & 79 \\
\hline Nem & 17 & 22 & 94 & 48 & 6 & 187 \\
\hline Total & 46 & 40 & 123 & 51 & 6 & 266 \\
\hline
\end{tabular}

Forrás: Saját szerkesztés, 2019

8. táblázat: Zöldségfogyasztásra vonatkozó kereszttáblás vizsgálat

Az egészséges táplálkozás másik vizsgált komponense a folyadékfogyasztás volt. A szakirodalomi áttekintésben bemutatott ajánlások alapján kérdeztük meg a hallgatók átlagos napi folyadékbevitelének mértékét (1. ábra). Az eredmények azt mutatják, hogy a férfiak jobban odafigyelnek a folyadékbevitelükre, mint a nők. A megkérdezett nők 47,5\%-a kevesebb, mint két liter folyadékot fogyaszt naponta, és mindössze $52,5 \%$ felel meg a napi ajánlásoknak. A férfiaknál már jóval kedvezőbb kép látható, hiszen a megkérdezettek közül csupán 18,1\% fogyaszt 2 liternél kevesebb folyadékot; és $81,9 \%$ pedig teljesíti az ajánlásokat.

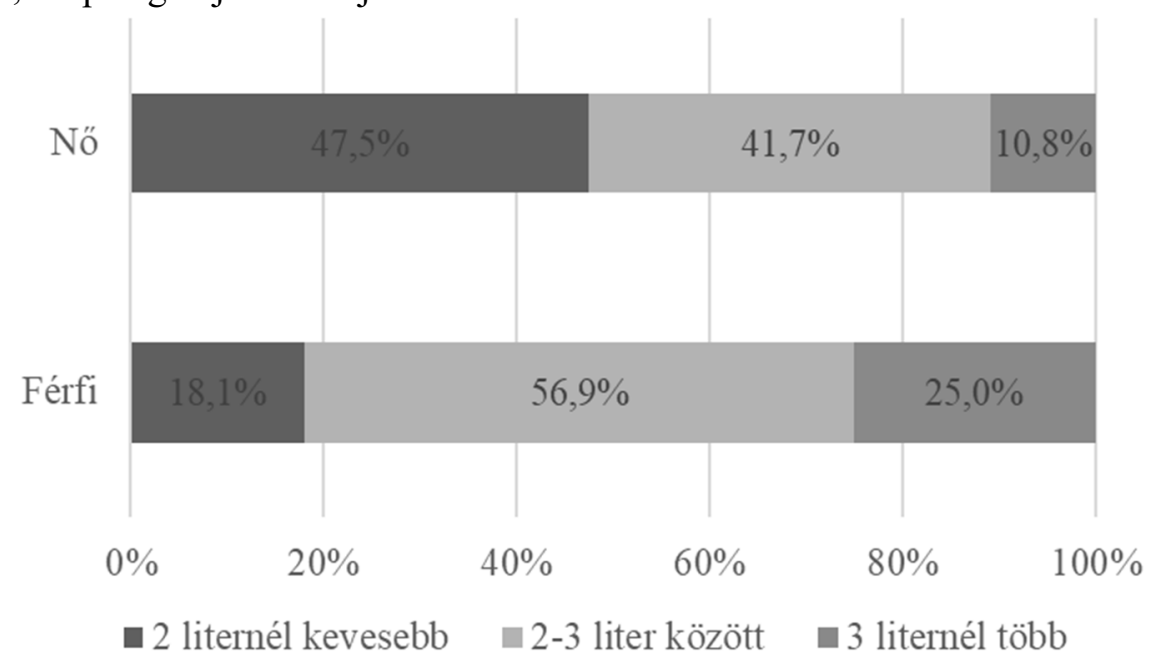

Forrás: Saját szerkesztés, 2019

1. ábra: Folyadékfogyasztás nem szerinti bontásban 
A két komponens együttes vizsgálatát a 9. táblázat mutatja be. A kereszttáblás vizsgálat a válaszadók átlagos napi folyadékbevitel mennyiségének és a napi ajánlott zöldség- és gyümölcsfogyasztás megoszlásának együttes alakulását mutatja be.

\begin{tabular}{|l|c|c|c|}
\hline \multirow{2}{*}{$\begin{array}{c}\text { Naponta átlagosan hány } \\
\text { liter folyadékot fo- } \\
\text { gyaszt? }\end{array}$} & $\begin{array}{c}\text { Naponta fogyaszt legalább 5 darab nyers zöldséget (bur- } \\
\text { gonya és zöldséglé nélkül) és/vagy gyümölcsöt? (Össz- } \\
\text { mennyiség 400 g) }\end{array}$ & $\begin{array}{c}\text { To- } \\
\text { tal }\end{array}$ \\
\cline { 2 - 4 } & \multicolumn{2}{|c|}{ Igen } & Nem \\
\hline 2 liternél kevesebb & 16 & 67 & 83 \\
\hline $2-3$ liter között & 45 & 87 & 132 \\
\hline 3 liternél több & 18 & 185 & 264 \\
\hline Total & 79 & & \\
\hline
\end{tabular}

Forrás: Saját szerkesztés, 2019

9. táblázat: Folyadék- és zöldség-, gyümölcsfogyasztást bemutató kereszttábla

Látható, hogy a vizsgálatban résztvevők közül 16 fő fogyaszt napi szinten megfelelö mennyiségü zöldséget és gyümölcsöt, ám az ajánlott napi folyadékbevitelt nem tartja be. Ennek az ellenkezője 118 före igaz, vagyis a napi ajánlott folyadékbevitel megfelelő, ám a zöldség és gyümölcsfogyasztás nem. Ezen vizsgálat alapján elmondható, hogy a megkérdezettek mindössze 23,8\%-a táplálkozik egészségesen, azaz a megfelelő menynyiségü zöldség/gyümölcsbevitellel és megfelelő mennyiségü folyadékbevitellel rendelkezik napi szinten. A kereszttáblás vizsgálat eredményei szignifikánsak a khi próba alapján, ám a függőségi kapcsolat nagyon gyenge (Phi és Cramer's V értékei 0,159).

\section{Következtetések, javaslatok}

Kutatásunk során a Debreceni Egyetem hallgatóságának egy részét mértük fel egészséges táplálkozási szokásaik szempontjából. Az egészséges táplálkozás két komponensét, a gyümölcs- és zöldségfogyasztást, valamint a folyadékbevitelt vizsgáltuk meg. Kutatási eredményeink alapján elmondhatjuk, hogy a megkérdezett hallgatók kevesebb, mint 15\%-a fogyaszt napi rendszerességgel gyümölcsöt és zöldséget. Nem szerinti bontásban vizsgálva nagymértékü különbség a napi fogyasztásban nem tapasztalható. A napi ajánlott folyadékmennyiséget a hallgatók több mint $65 \%$-a eléri, vagy meg is haladja. Ám ezen arány kialakulásához leginkább a férfiak fogyasztása járul hozzá, hiszen a megkérdezett férfiak 81,9\%-a, míg a nők csupán 52,5\%-a fogyaszt az ajánlásoknak megfelelő mennyiségü folyadékot. A két tényező együttes vizsgálatából kiderül, hogy a megkérdezett hallgatók mindössze 23,8\%-a táplálkozik egészségesen, azaz a zöldség- és gyümölcsbevitel, valamint a folyadékbevitel is az ajánlásoknak eleget tesz. 
Nemzetközi kitekintésként elmondható, hogy a finn egyetemi hallgatóság többsége szintén fontosnak tartotta az egészséges táplálkozást. El Ansari - Suominen - Samara (2015) tanulmányában szignifikáns kapcsolatot mutattak ki az egészséges táplálkozás és a megkérdezésben meghatározott összes élelmiszercsoport között - kivéve az édességek és sütemények élelmiszercsoportot. Kutatási eredményeik a zöldség és gyümölcs fogyasztás esetében sokkal kedvezőbb képet mutat. A megkérdezett hallgatók $52 \%$-a fogyaszt napi rendszerességgel gyümölcsöt és a rendszeres zöldségfogyasztás (nyers zöldség - 68,5\%, főtt zöldség 28,6\%) is jóval nagyobb hányadot mutat a saját mintámhoz képest. Egy másik, amerikai kutatás szintén felmérte az egyetemi hallgatóságot, mely felmérés tartalmazta a zöldség és gyümölcsfogyasztás gyakoriságának a felmérését (Silliman - Rodas-Fortier - Neyman, 2004). A kutatás eredményei azt mutatták, hogy a megkérdezett férfiak 67\%-a fogyaszt legalább napi szinten egy adag zöldséget, míg a nök esetében ez 57\%. A gyümölcsfogyasztásról pedig elmondható, hogy a megkérdezett nők 42\%-a, míg a férfiak csupán 29\%-a fogyaszt az ajánlásoknak megfelelő mennyiséget naponta (Silliman - Rodas-Fortier - Neyman, 2004).

Ezek alapján láthatjuk, hogy a zöldség és gyümölcsfogyasztás esetében kedvezőbb helyzetben van Finnország nálunk, ám az amerikaiak tőlünk is lemaradnak. Egy egészségmutatót, az elhízást vizsgálva szintén ezt a sorrendet láthatjuk (OECD, 2017), amelyet mért adatok támasztanak alá. A globális elhízási rangsor esetében az Amerikai Egyesült Államok az első helyen áll, míg Magyarország a negyedik, Finnország pedig a kilencedik. Szintén egy másik egészségmutató esetében megfigyelhető a finnek jobb egészségügyi helyzete, hiszen a születéskor várható élettartamuk közel 72 év, míg a magyarok és az amerikaiak közel azonos értékkel jóval elmaradnak (WHO, 2018b).

Fontos javaslatként megfogalmazni azt, hogy az egyetemi hallgatók figyelmét fel kell hívni az egészséges táplálkozásra, hiszen számos betegség megelözésére alkalmas; és már azzal tehetnek egészségük megóvása érdekében, hogy a táplálkozási ajánlásokat betartják.

\section{Felhasznált irodalom}

1. Deliens, T., Clarys, P., De Bourdeaudhuij, I., Deforche, B. (2014): Determinants of eating behaviour in university students: a qualitative study using focus group discussions. BMC Public Health. 2014; 14: 53. DOI: https://doi.org/10.1186/1471-2458-14-53

2. Dietary Guidelines (2015): 2015-2020 Dietary Guidelines for americans. eighth edition, https://health.gov/dietaryguidelines/2015/guidelines/

3. Elef 2014 (2018): A 2014-ben végrehajtott európai lakossági egészségfelmérés eredményei - Összefoglaló adatok. Központi Statisztikai Hivatal, pp. 33 http://www.ksh.hu/docs/hun/xftp/idoszaki/elef/elef2014_osszefoglalo.pdf

4. El Ansari, W., Suominen, S., Samara A. (2015): Eating Habits and Dietary Intake: Is Adherence to Dietary Guidelines Associated with Importance of Healthy Eating among Undergraduate University Students in Finland?, Cent Eur J Public Health, 23 (4) pp. 306-313, DOI: https://doi.org/10.21101/cejph.a4195 
5. Gandy, J. (2015): Water intake: validity of population assessment and recommendations. European Journal of Nutrition, Volume 54, Supplement 2, pp 11-16 DOI: https://doi.org/10.1007/s00394-015-0944-8

6. Jéquier, E., Constant, F. (2010) Water as an essential nutrient: the physiological basis of hydration. European Journal of Clinical Nutrition, Vol. 64, pp. 115-123 DOI: https://doi.org/10.1038/ejen.2009.111

7. Silliman, K., Rodas-Fortier, K., Neyman, M. (2004): A Survey of Dietary and Exercise Habits and Perceived Barriers to Following a Healthy Lifestyle in a College Population, Californian Journal of Health Promotion, Volume 2, Issue 2, pp. 10-19 DOI: _ https://doi.org/10.32398/cjhp.v2i4.900

8. Mednyánszky Zsuzsa (2002): Zöldség és gyümölcsfélék a sportolók táplálkozásában. Magyar Sporttudományi Szemle 2002/2., pp. 23-24

9. Niva, M. (2007): All Foods Affect Health': Understandings of Functional Foods and Healthy Eating Among Health-Oriented Finns. Appetite. 2007. 48. pp. 384-393, DOI: https://doi.org/10.1016/j.appet.2006.10.006

10. OECD (2017): Obesity Update 2017, www.oecd.org/health/obesity-update.htm

11. Pfau Christa, Müller Anetta, Bács Zoltán, Bácsné Bába Éva (2018): Az egészséges táplálkozás szerepe és jelentősége. Táplálkozásmarketing, V. évfolyam, 2018/1. szám, pp. 49-63, doi: https://doi.org/10.20494/tm/5/1/4

12. Vitrai József, Bakacs Mária, Varsányi Péter (2017): Hazai egészség-pillanatkép, 2017. Egészségfejlesztés, LVIII. évfolyam, 4. szám, pp. 59-75, doi: 10.24365/ef.v58i4.205

13. WHO (2018a): Healthy diet. https:/www.who.int/news-room/fact-sheets/detail/healthy-diet

14. WHO (2018b): Healthy life expectancy (HALE) Data by country, http://apps.who.int/gho/data/view.main.HALEXv

15. WHO (2019): Increasing fruit and vegetable consumption to reduce the risk of noncommunicable diseases.

https://www.who.int/elena/titles/fruit_vegetables_ncds/en/ 